\section{The power of the mind}

\author{
Ghost: A Novel \\ by Alan Lightman \\ Pantheon: 2007. 256 pp. \$23
}

\section{Janna Levin}

Few writers are able to harness fully the narrative potential of science in fiction. Some stunning novels touch on science tangentially, investing more in the grim consequences, such as Cormac $\mathrm{McCa}$ rthy's post-apocalyptic masterpiece, The Road, and Kazuo Ishiguro's haunting twist on genetic ethics, Never Let Me Go. As a gifted physicist and writer, Alan Lightman brings unique sensibilities to this context, structuring his works around scientific themes. His visionary first work of fiction, published in 1993, was Einstein's Dreams, a series of poetic vignettes, meditations on the theory of relativity. The book's success lies in Lightman's ability to draw out the fantastical aspects of scientific theory while simultaneously reflecting some simple facet of our intimate human desires an accomplishment that won him many accolades. In his latest novel, Ghost, Lightman considers another aspect to the overlap of sense and sensation, a more troubled but delicately illustrated tension between reason and belief, between the ordinary and the extraordinary.

Ghost is the story of an extraordinary event experienced by an ordinary man. David has seen something he cannot name or explain. $\mathrm{He}$ is not given to fantasies of the supernatural. He is a reasonable person, intelligent, hard working and fair-minded, if lacking in ambition. Languishing after a painful divorce and unexpectedly losing his long-held job at the bank, he stumbles into an apprentice position at a local mortuary. And it is there, where the bodies rest for viewing, that he sees something inexplicable.

He is terrified, not by the vision but by the threat to his rationality. He is analytically

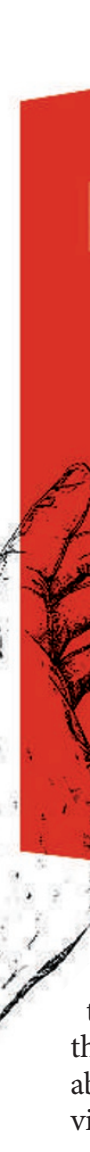

thinking, but he is sure that it was no trick of the light or hallucination. Deeply embarrassed about his experience, he hesitantly describes the vision to Ellen, the woman with whom he has an emotionally sparse but highly sexual relationship. The story quickly spreads through the community of stragglers in the decrepit apartment building in which he lives alone in one shabby room. The local newspaper carries the headline: "Mortuary worker claims to see ghost".

David becomes an ambivalent ally to the Society of the Second World, while maintaining a confused yet sincere alliance with their opposition, a group of scientists at the local university. David agrees to let them carry out public experiments to measure his psychic ability to affect a random-number generator enclosed in a black box.

This is one interpretation of the story. There is another. David, although not very ambitious, is not without vanity. For years he exaggerates to his mother his importance at the bank, pretending that he is the manager. He struggles daily with the humiliation of his wife's rejection and seizes on the opportunity to appear important to her, to seem valuable and significant. He is not rabidly egotistical, just vulnerable enough to believe that he can affect a black box with his mind. He needs to believe that he is special - "You've been chosen," Ellen tells him — and so he does believe it.

His failure to fully understand the scientists' statistical arguments allows him to indulge in this fairly mild delusion of self-importance. He is genuinely uncomfortable with the public attention he receives, but needs to be believed by those close to him. Even here he lacks ambition. He has no inclination to claim that he has psychically altered major world events, as the Society of the Second World's propaganda declares, just that he can affect the black box. He cannot quite accept that his experience was nothing significant.

Once again, Lightman cleverly navigates a precarious line between science and belief. The facts of David's experience are never resolved. Lightman allows just enough ambiguity for you to impose your own beliefs, in the absence of proof. He could easily mock his characters' weaknesses, but instead he evokes our sympathies and challenges us all, rationalists included.

Lightman's writing has an elegant and light touch. There are lovely descriptions of the processes the corpses undergo: the embalming, the sewing together of the lips, the
"Lightman considers a tension between reason and belief, between the ordinary and the extraordinary." colouring of the faces. All the while, in and out of the mortuary, there are subtle reflections on death and our fears about life. As we are lost in this ordinary man's world, the story sneaks up on us, understated and beautiful, until, before we realize it, something extra-

ordinary has happened.

Janna Levin is a professor in the Department of Physics and Astronomy at Barnard College of Columbia University, 3009 Broadway, New York 10027, USA, and is the author of the novel A Madman Dreams of Turing Machines (Knopf, 2006).

\section{The Cutter Incident: How America's First Polio} Vaccine Led to the Growing Vaccine Crisis by Paul Offit (Yale University Press, \$17) In 1955, shortly after the development of the polio vaccine, some 200,000 people were mistakenly injected with live, virulent polio vaccine. Vaccine researcher Paul Offit discusses what went wrong, and shows how it has had a devastating effect on vaccine production ever since. "A superb job," wrote Paul-Henri Lambert (Nature Med. 12, 879; 2006).

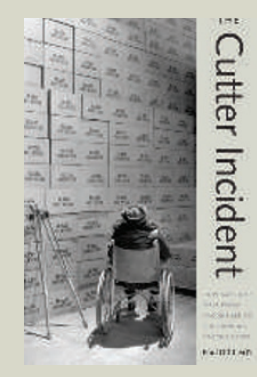

Every Second Counts: The Extraordinary Race to Transplant the First Human Heart by Donald McRae (Pocket Books, £7.99)

Forty years ago the race was on to perform the first human heart transplant. Every Second Counts is a gripping account of how the South African doctor Christiaan Barnard came from nowhere to secure his place in medical history. McRae details how Barnard pipped to the post three other surgeons who were also poised, having spent years perfecting their techniques.
Donald McRae secorid counts

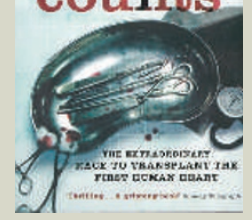

